\title{
Purification of $\alpha$-lactalbumin from a prepurified acid whey: Ultrafiltration or precipitation
}

\author{
Arabelle MULLER ${ }^{\mathrm{a}}$, Bernard CHAUFER ${ }^{\mathrm{b}}$, Uzi MERIN ${ }^{\mathrm{c}}$, Georges DAUFIN ${ }^{\mathrm{a} *}$ \\ ${ }^{a}$ Laboratoire de Recherches de Technologie Laitière, INRA, 65 rue de Saint-Brieuc, \\ 35042 Rennes Cedex, France

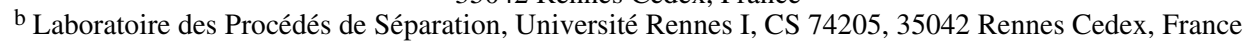 \\ ${ }^{\mathrm{c}}$ Dairy Science Laboratory, A.R.O., The Volcani Center, PO Box 6, Bet Dagan 50250, Israel
}

(Received 4 November 2002; accepted 2 June 2003)

\begin{abstract}
Acid casein whey is a co-product of casein manufacture that contains a protein, $\alpha$-lactalbumin, with high nutritional and biological properties. The target protein can be purified using a two-step cascade. The previously reported first step consists of ultrafiltration, which aims at producing a tailor-made permeate with a decreased content of contaminants (bovine serum albumin, immunoglobulins) down to zero and enhanced $\alpha$-lactalbumin/ $\beta$-lactoglobulin ratio. The second step is described in the present work. Two routes were investigated. The ultrafiltration route consisted of a second ultrafiltration step with an appropriate membrane, transmembrane pressure, ionic strength and protein concentration. As expected, the purity of $\alpha$-lactalbumin was satisfactory $(0.65)$ but the yield was poor $(0.15)$ due to the low transmission of $\alpha$-lactalbumin $(<0.2)$. The precipitation route (reversible precipitation of $\alpha$-lactalbumin) was more promising, provided proper conditions (initial protein concentration, precipitation $\mathrm{pH}$, length of precipitation time and number of precipitate washings) were maintained. The purity was in the range $0.77-0.99$ depending on the feed generated by the first step of the operation (microfiltration and ultrafiltration). The yield of the insoluble route was satisfactory $(0.46-0.83)$. The role of operating parameters for both routes was investigated.
\end{abstract}

$\alpha$-lactalbumin / purification / process / whey

Résumé - Purification d' $\alpha$-lactalbumine à partir d'un lactosérum acide prépurifié : ultrafiltration ou précipitation. Le lactosérum acide, co-produit de la fabrication de caséines, contient une protéine, l' $\alpha$-lactalbumine, ayant des propriétés nutritionnelles et biologiques. La protéine peut être purifiée en deux étapes. La première étape, récemment rapportée, est une ultrafiltration qui vise à produire un perméat sur mesure pour la seconde étape avec une teneur quasi-nulle en protéines contaminantes (sérum albumine bovine, immunoglobulines) et un rapport $\alpha$-lactalbumine/ $\beta$-lactoglobuline augmenté. La deuxième étape est l'objet du présent article. Deux voies étaient étudiées. La première utilisait une deuxième étape d'ultrafiltration avec une membrane et des conditions opératoires (pression transmembranaire, force ionique et concentrations en protéines) appropriées. La pureté de l' $\alpha$-lactalbumine était satisfaisante $(0,65)$ mais le rendement faible $(0,15)$ en raison de la faible transmission de l' $\alpha$-lactalbumine $(<0,2)$. La seconde voie, basée sur la précipitation réversible de l' $\alpha$-lactalbumine, était plus prometteuse sous réserve de bien sélectionner la concentration initiale en protéines, le $\mathrm{pH}$ et la durée de précipitation, et le nombre de lavages du précipité. La pureté de l'ordre de 0,77-0,99 dépendait du produit obtenu après la

\footnotetext{
* Corresponding author: arenouar@labtechno.roazhon.inra.fr
} 
première étape (microfiltration, ultrafiltration). Le rendement de cette deuxième étape (voie précipitation) était satisfaisant $(0,46-0,83)$. Le rôle des paramètres opératoires pour les deux voies est discuté.

\section{Q-lactalbumine / purification / procédé / lactosérum}

\section{INTRODUCTION}

Whey is a co-product of cheese-making and the casein industry. It represents a considerable amount of proteins and is produced in large quantities [15].

Several investigators have proposed a two-main-step process for the recovery of $\alpha$-lactalbumin, $\alpha$-LA. Most of the proposed schemes take advantage of selective and reversible aggregation of $\alpha$-LA (hereafter called the precipitation route) at acidic $\mathrm{pH}$ below its isoelectric $\mathrm{pH}[3,7$, $17-19,23]$ as the first step in order to separate it from the main whey protein, $\beta$ lactoglobulin, $\beta-\mathrm{LG}$, by sedimentation. The second step deals with the solubilisation of the co-precipitated fraction of $\alpha-\mathrm{LA}$, bovine serum albumin, BSA, and immunoglobulins, Ig, by adjusting its $\mathrm{pH}$ to $\sim 7$ at room temperature. $\alpha$-LA purity reported for the above two-step process is in the range $0.62-0.64$ with a yield of $0.80-0.70$, respectively $[7,20]$. A $\alpha$-LA fraction from rennet casein whey is fully soluble in $\mathrm{NaCl}$ or $\mathrm{CaCl}_{2}$ with purity ranging between 0.56 and 0.79 and a yield of 0.81 to 0.65 , respectively [4]. From Cheddar cheese whey, a $\alpha$-LA precipitated fraction ranging from 23 to $35.8 \%$ of the total protein nitrogen is obtained [18]; unfortunately, the purity cannot be calculated as the contaminants of this fraction are not given. For the $\beta$-LG co-fraction both purity and yield could reach 0.85 [7]. Precipitation can also occur at $\mathrm{pH} 7.3$ at $50{ }^{\circ} \mathrm{C}$ after addition of $\mathrm{CaCl}_{2}$ [22]. Permeate from microfiltration (MF) contains $\alpha$-LA and $\beta$-LG with a $1 /$ $1 \mathrm{w} / \mathrm{w}$ content, which are concentrated by ultrafiltration, UF, in a first step (ratio of 1/ 1) before being precipitated at $\mathrm{pH} 3.7$; final $\alpha$-LA purity is close to 0.75 .
High concentration of the conformer (A)- $\alpha$-LA from Cheddar whey has been reported [24]. The striking point is an acidification step at $\mathrm{pH}<4.0$ which induces a conformational change of $\alpha$-LA which becomes larger. Two routes are followed in order to obtain $\alpha$-LA concentrate. For the precipitation route, $\mathrm{pH}$ is raised to 4.6 at $25-40{ }^{\circ} \mathrm{C}$; the precipitate fraction has $\alpha$ LA purity of about 0.28 (as referred to total protein). The ultrafiltration route process involves a concentration step (up to a volume reduction ratio, VRR, 10) with optional diafiltration, DF: $\alpha$-LA purity is between 0.37 and 0.65 (vs. total protein) depending on diafiltration volumes and the rig used. Numerous works aim at operating cross-flow or dead-end MF and UF in one or two steps, sometimes including a diafiltration step $[1,2,10,11,12,20]$. It appears that $\alpha$-LA purity remains limited $(0.12$ 0.3 ) unless the yield close to 0 permits a purity of 0.83 to be achieved [11].

Ion exchange chromatography is reported as an alternative to membrane processes $[16,21]$. The range of $\alpha$-LA purity (vs. protein) can reach $0.6-0.68$ with residual contamination of lactose [21] and glycomacropeptide (GMP) [16].

A cascade of two steps is proposed to enrich $\alpha$-LA purity [13]. The first step consists of an UF separation performed with proper operating conditions: a $300 \mathrm{~kg} \cdot \mathrm{mol}^{-1}$ molecular mass cut-off (MMCO) inorganic membrane, clarified acid casein whey, $\mathrm{pH} 7.0$, ionic strength: $0.2 \mathrm{~mol} \cdot \mathrm{L}^{-1}$, protein concentration: $7 \mathrm{~g} \cdot \mathrm{L}^{-1}$, continuous concentration up to VRR 11, tangential flow velocity: $6 \mathrm{~m} \cdot \mathrm{s}^{-1}$, temperature $50{ }^{\circ} \mathrm{C}$ and transmembrane pressure: $\Delta \mathrm{P} 1.0 \mathrm{bar}$ [15]. This first step yields a permeate with increased $\alpha$-LA purity $(0.44$ vs. 0.25 
initially) and a satisfactory yield ( 0.53 with continuous concentration). Such a permeate is a good example of tailor-made feed for the second step of the cascade.

The aim of the present work is to report on about the second step of the cascade according to two different routes. The objective of this work was to use the existing scientific knowledge regarding selective separation of proteins by ultrafiltration and of $\alpha$-LA by selective precipitation so as to show how to achieve high $\alpha$-LA purity by taking advantage of the major information known about the role of operation parameters. The first route consisted of an additional UF step, where operating conditions (protein concentration, ionic strength and transmembrane pressure) were varied to limit fouling and concentration polarisation with the aim of getting a high $\alpha$-LA transmission/ $\beta-\mathrm{LG}$ transmission ratio. From previous works cited in the above review and the basic principles which rule the combination purity-yield closely connected to protein transmission [13,14], it is anticipated that in the ultrafiltration route any small increase in $\alpha$-LA purity will be detrimental to yield. In the second route, $\alpha$-LA was precipitated and then solubilised. The effect of different parameters which govern the precipitation reaction, such as $\alpha$-LA concentration, initial $\alpha$-LA purity, ionic strength, sodium citrate addition, and the temperature of the solubilisation step were studied. It will be shown that the insoluble route permitted the preparation of a $\alpha$-LA fraction with higher purity and yield as compared with previous patents and reports.

Currently, commercial powders with high $\alpha$-LA content contain 60 to $90 \%$ total protein referred to dry matter with $\alpha$-LA purity (referred to total protein) in the range $0.15-0.40$ and a $\alpha-\mathrm{LA} / \beta-\mathrm{LG}$ ratio of between 1 and 2 . The market is around $400 \mathrm{t} / \mathrm{y}$. The industrial manufacturing processes vary: chromatography, heat-coagulation or membrane separation (UF + MF).
We undertook this project after cautiously considering that the compulsory first stage was to show which process schemes permit the preparation of high purity $\alpha$-LA fractions. From there on, it will later be possible to figure out the evolution of $\alpha$-LA structure, functional and biological properties in each successive fraction at each step of the final process.

\section{MATERIALS AND METHODS}

\subsection{Feeds}

The feeds used in the present work were prepared according to the principles of $\alpha-$ LA prepurification reported by Muller et al. [15]. Nonetheless, the actual operating conditions were adapted to the whey protein fractions specially selected for the present work.

Raw hydrochloric acid casein whey protein concentrates, Protarmor PS 75 and PS 90 were manufactured by Armor Protéines, Saint-Brice-en-Coglès, France. Detailed flow-sheets for the industrial manufacture of liquids PS 75 and PS 90 have been reported by Muller [13] and Gésan et al. [9]. PS 90 ultrafiltrate and PS 90 microfiltrate were prepared as described by Muller et al. [15] and were used as feeds for the ultrafiltration route (Fig. 1). Concentrated PS 90 ultrafiltrate and PS 75 microfiltrate, used for the precipitation route, were obtained according to Figure 1. The compositions of the four whey protein fluids used in this work are given in Tables I and II.

PS 90 ultrafiltrate was an appropriate material for exploring the route of the reversible thermal-isoelectric precipitation of $\alpha$-LA: owing to the fairly good initial purity of $\alpha$-LA $(0.43$; Tab. I) and the absence of BSA and IgG, high final $\alpha-\mathrm{LA}$ purity can be expected. However, $\alpha$-LA concentration was smaller than that required $\left(>2 \mathrm{~g} \cdot \mathrm{L}^{-1}\right)$ to achieve an aggregation yield over 0.6 [4]. Therefore, PS 90 ultrafiltrate 


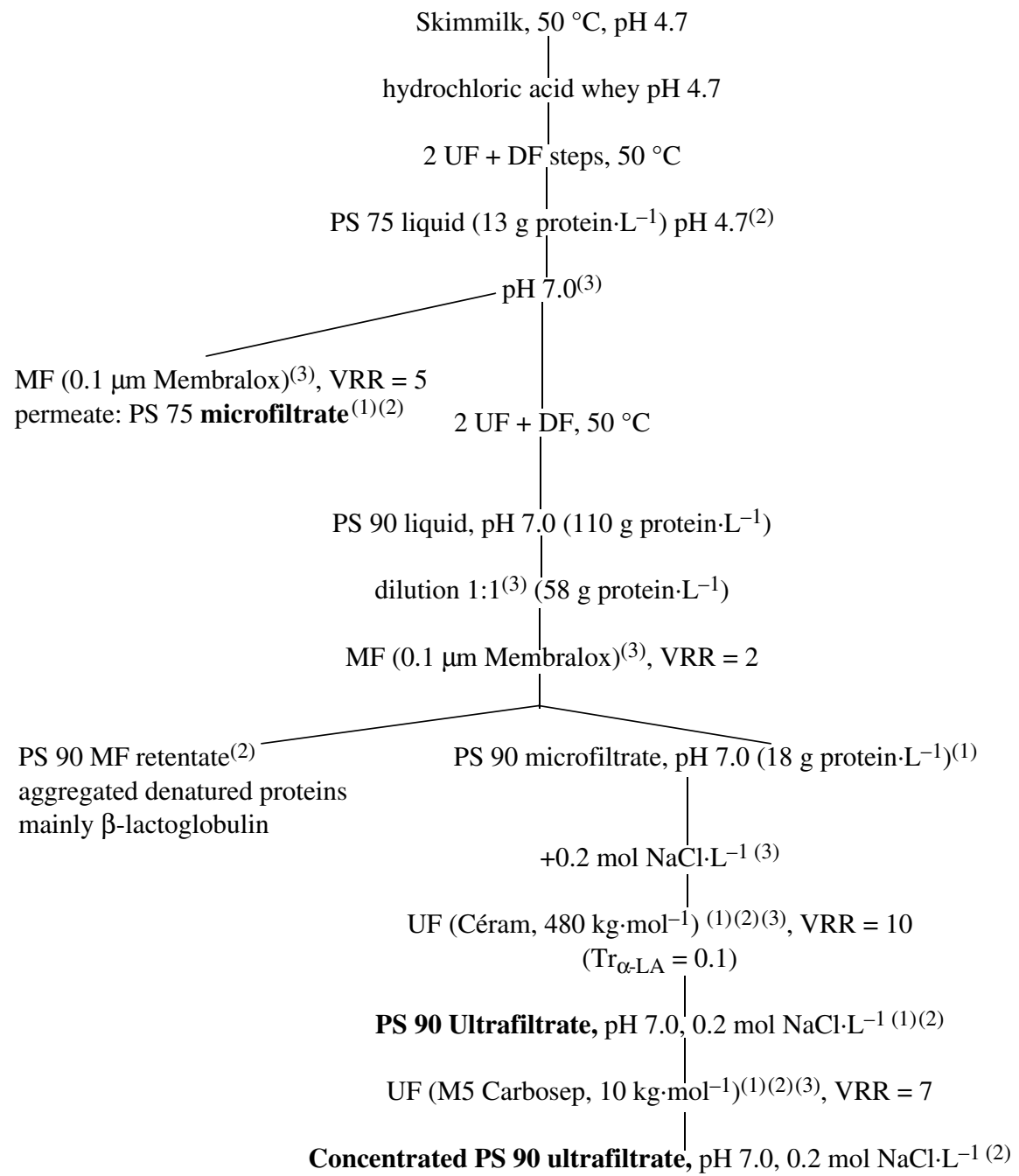

Figure 1. Flow-sheet for the achievement of whey protein concentrates enriched in $\alpha$-lactalbumin. Ultrafiltration route: PS 90 microfiltrate; PS 90 ultrafiltrate. Precipitation route: concentrated PS 90 ultrafiltrate; PS 75 microfiltrate.

(1) No turbidity occurred; (2) reverse phase chromatography profiles for $\alpha$-LA and $\beta$-LG were identical to those for pure proteins from Sigma and from BiPro Sweet Whey Protein Isolate (manufactured by anion exchange chromatography process at $\mathrm{pH} 7.0$ ); (3) performed on a laboratory scale.

$\mathrm{DF}=$ diafiltration; $\mathrm{MF}=$ microfiltration; $\mathrm{UF}=$ Ultrafiltration; $\mathrm{VRR}=$ volume reduction ratio; $\operatorname{Tr}_{\alpha-\mathrm{LA}}=\alpha$-lactalbumin transmission. 
Table I. Main features of feeds used for the ultrafiltration route performed on a laboratory scale.

\begin{tabular}{lccc}
\hline & PS 90 microfiltrate & \multicolumn{2}{c}{ PS 90 ultrafiltrate } \\
\hline Total protein concentration in the feed $\left(\mathrm{g} \cdot \mathrm{L}^{-1}\right)$ & 15 & 1.6 & 7.0 \\
$\alpha$-LA concentration $\left(\mathrm{g} \cdot \mathrm{L}^{-1}\right)$ & 5.0 & 0.7 & 2.45 \\
Purity (-) & & & \\
$\mathrm{P}_{\alpha-\mathrm{LA}}$ & 0.33 & 0.43 & 0.35 \\
$\mathrm{P}_{\beta-\mathrm{LG}}$ & 0.65 & 0.57 & 0.65 \\
$\mathrm{P}_{\mathrm{BSA}+\mathrm{IgG}}$ & $<0.02$ & 0 & 0 \\
$\mathrm{~A}_{600}($ a.u. $)\left(\mathrm{C}_{\text {tot }}=1.6 \mathrm{~g} \cdot \mathrm{L}^{-1}\right)$ & 0.04 & 0.06 & $\mathrm{nd}$ \\
$\mathrm{pH}\left(50^{\circ} \mathrm{C}\right)$ & 7.0 & 7.0 & 7.0 \\
$\chi\left(\mathrm{mS} \cdot \mathrm{cm}^{-1}\right)\left(50^{\circ} \mathrm{C}, \mathrm{C}_{\text {tot }}=1.6 \mathrm{~g} \cdot \mathrm{L}^{-1}\right)$ & 2.18 & 22.00 & $\mathrm{nd}$ \\
Filtration steps & {$[4] *+1$} & {$[4] *+2$} & {$[4] *+3$} \\
\hline
\end{tabular}

A : Absorbance at $600 \mathrm{~nm}\left(\mathrm{~A}_{600}\right) ; \chi:$ : conductivity; $:$ not detected after a volume reduction ratio of 7 ; [ ] *: number of steps performed on an industrial scale; + number of filtration steps performed according to Figure 1; a.u.: absorbance unit; nd: not determined.

Table II. Feeds used for the precipitation route, performed on a laboratory scale: protein composition, molar ratio $\mathrm{C}_{\mathrm{Ca}} / \mathrm{C}_{\alpha-\mathrm{LA}}$, initial conductivity, $\chi$ and history of the whey protein concentrates.

\begin{tabular}{lcc}
\hline & Concentrated PS 90 ultrafiltrate & PS 75 microfiltrate \\
\hline Total protein concentration in the feed $\left(\mathrm{g} \cdot \mathrm{L}^{-1}\right)$ & 12.3 & $\begin{array}{c}\text { Freeze dried powder } \\
\text { adjustable }\end{array}$ \\
$\alpha$-LA concentration $\left(\mathrm{g} \cdot \mathrm{L}^{-1}\right)$ & 4.3 & \\
Purity (-) & & 0.17 \\
$\mathrm{P}_{\alpha-\mathrm{LA}}$ & 0.35 & 0.81 \\
$\mathrm{P}_{\beta-\mathrm{LG}}$ & 0.65 & 0.015 \\
$\mathrm{P}_{\mathrm{BSA}}$ & 0.00 & 0.005 \\
$\mathrm{P}_{\mathrm{IgG}}$ & 0.00 & 11.0 \\
Molar ratio $\mathrm{C}_{\mathrm{Ca}} / \mathrm{C}_{\alpha-\mathrm{LA}}(-)$ & 7.0 & 5.65 \\
$\chi\left(\mathrm{mS} \cdot \mathrm{cm}^{-1}\right)\left(20^{\circ} \mathrm{C}, \mathrm{pH} 7.3, \mathrm{C}=6.4 \mathrm{~g} \cdot \mathrm{L}^{-1}\right)$ & 17.80 & \\
& $\left(0.2 \mathrm{~mol} \cdot \mathrm{NaCl} \cdot \mathrm{L}^{-1}\right)$ & {$[2] *+1$} \\
Filtration steps & {$[4] *+3$} &
\end{tabular}

- Not detected at a total protein concentration of $12.3 \mathrm{~g} \cdot \mathrm{L}^{-1}$; [ ] * performed on an industrial scale; + number of filtration steps performed according to Figure 1 .

was concentrated up to a VRR of 7 by using a $\mathrm{M} 5$ Carbosep membrane, $\mathrm{MMCO}=$ $10 \mathrm{~kg} \cdot \mathrm{mol}^{-1}$ (ORELIS, Saint-Maurice-deBeynost, France); some losses of $\alpha$-LA $\left(\operatorname{Tr}_{\alpha-L A}\right.$ in the range $0-0.07 ; \operatorname{Tr}_{\beta-L G}$ in the range $0-0.01$ in a 3 -h UF run) yielded a decrease in $\alpha$-LA purity (0.35) (Tabs. I and II).

PS 75 microfiltrate contained a small amount of BSA and $\operatorname{IgG}(<2 \%$, Tab. II) but had a short history (three filtration steps) and a low ionic strength. To avoid lowered $\alpha$-LA purity it was not concentrated by UF but freeze-dried.

\subsection{Ultrafiltration route}

Ultrafiltration of PS 90 microfiltrate and PS 90 ultrafiltrate was performed with a laboratory rig previously described [6]. The $50 \mathrm{~kg} \cdot \mathrm{mol}^{-1} \mathrm{MMCO}$ (average pore diameter: $12.4 \mathrm{~nm}$ ) Céram membrane (TAMI Industries, Nyons, France) had 
three channels $1.20 \mathrm{~m}$ in length, a $3.6 \mathrm{~mm}$ inner hydraulic diameter and a filtering area of $0.045 \mathrm{~m}^{2}$. The support was of $\alpha-$ alumina with the filtering layer of zirconium oxide with a clean membrane hydraulic resistance of $1.6 \times 10^{12} \mathrm{~m}^{-1}$. This membrane was selected because a high ratio $\frac{\operatorname{Tr}_{\alpha-L A}}{\operatorname{Tr}_{\beta-L G}}(\operatorname{Tr}=$ transmission $)$ was expected according to Ferry's equation [8].

Standard operating conditions were as follows: pH 7.0 (regular pH of both PS 90 microfiltrate and PS 90 ultrafiltrate); tangential flow velocity $-3.4 \mathrm{~m} \cdot \mathrm{s}^{-1}$ (wall shear stress: $43 \mathrm{~Pa}$ ) and dynamic counterpressure (constant transmembrane pressure along the filtering path so as to reduce limiting phenomena (fouling, deposit and concentration polarisation); TMP $=1.0$ bar; $50{ }^{\circ} \mathrm{C}$, and continuous concentration mode up to a VRR around 7.0 after $3.5 \mathrm{~h}$ UF time depending on the UF flux, which varied with the nature and concentration of the feed used, PS 90 microfiltrate and PS 90 ultrafiltrate, and with ionic strength. The ionic strength defined below covers the added salts $(\mathrm{NaCl})$ since the initial ionic content of the protein concentrate was shown to be negligible (around $0.005 \mathrm{~mol} \cdot \mathrm{L}^{-1}$ equivalent $\mathrm{NaCl}$ through conductivity measurements) in all of the protein concentrates used in the experiments, due to the diafiltration steps performed in the industrial process scheme (Fig. 1). Three parameters known to be greatly involved in fouling and protein transmission were investigated in separate experiments where only part of the operating conditions were changed, i.e.: total protein concentration, $\mathrm{C}_{\text {tot }}$, in combination with ionic strength, $\mathrm{I}:\left(\mathrm{C}_{\mathrm{tot}}=\right.$ $\left.1.6 \mathrm{~g} \cdot \mathrm{L}^{1} ; \mathrm{I}=0.2 \mathrm{~mol} \cdot \mathrm{L}^{-1} \mathrm{NaCl}\right),\left(\mathrm{C}_{\mathrm{tot}}=\right.$ $\left.1.6 \mathrm{~g} \cdot \mathrm{L}^{-1} ; \quad 0.04 \mathrm{~mol} \cdot \mathrm{L}^{-1} \mathrm{NaCl}\right), \quad\left(\mathrm{C}_{\mathrm{tot}}=\right.$ $7.0 \mathrm{~g} \cdot \mathrm{L}^{-1} ; \mathrm{I}=0.04 \mathrm{~mol} \cdot \mathrm{L}^{-1} \mathrm{NaCl}$ ) with the feed PS 90 ultrafiltrate at TMP $=1.0$ bar, on the one hand, and transmembrane pressure $(\mathrm{TMP}=0.5,1.0$, and 2.0 bar $)$ with PS 90 microfiltrate $\left(7 \mathrm{~g} \cdot \mathrm{L}^{-1}\right.$; and $\left.\mathrm{I}=0.04 \mathrm{~mol} \cdot \mathrm{L}^{-1}\right)$ on the other hand. In the TMP series of experiments the observed VRR after $3 \mathrm{~h}$
UF was 3.3, 7.2 and 9.8, respectively, depending on flux. Thus, after a given time of UF, the VRR, the filtered volume and the retentate protein concentration were different. The VRR will be used as a more appropriate global macroscopic operating parameter than time to describe UF processing.

Prior to and after an UF experiment the membrane was cleaned according to a sequence: alkaline cleaning (P3 Ultrasil 13, Henkel Ecolab, Issy-les-Moulineaux, $1 \% \mathrm{w} / \mathrm{w}, \mathrm{pH} 13,85^{\circ} \mathrm{C}, 30 \mathrm{~min}$ ) and acid cleaning $\left(0.06 \mathrm{~mol} \cdot \mathrm{L}^{-1} \mathrm{HNO}_{3}, \mathrm{pH} 1.2\right.$, $60{ }^{\circ} \mathrm{C}, 20 \mathrm{~min}$ ), each followed by a pure water rinse.

\subsection{Precipitation route}

Operating conditions for $\alpha$-LA precipitation were as follows (unless specified): acidification with $2.5 \mathrm{~N}$ citric acid, heat treatment: $55^{\circ} \mathrm{C}, 120 \mathrm{~min}$; centrifugation: $4000 \mathrm{~g}, 30 \mathrm{~min}, 20^{\circ} \mathrm{C}$ and two washings of the sediment with osmosed water.

Prior to the study of the process parameters the optimal precipitation $\mathrm{pH}$ was assessed for each feed vs. total protein concentration and ionic strength. This $\mathrm{pH}$ enabled the best $\alpha$-LA precipitation yield.

The process parameters studied were:

- number of washing steps $(1 ; 2)$ of the sediment and solubilisation solvent (water, $0.05 \mathrm{~mol} \cdot \mathrm{L}^{-1} \mathrm{NaCl}$ and $0.05 \mathrm{~mol} \cdot \mathrm{L}^{-1}$ $\mathrm{CaCl}_{2}$ ) at $\mathrm{pH} 7.5$ with concentrated PS 90 ultrafiltrate;

- initial $\alpha$-LA concentration, precipitation temperature and precipitation kinetics with PS 90 microfiltrate.

The operating conditions of the six experiments performed are collected together in Table III.

\subsection{Analyses}

The four main proteins were quantified by RP-HPLC according to Muller et al. [14]. Owing to the absolute error on protein concentration $\left(\Delta \mathrm{C}=22.5 \mathrm{mg} \cdot \mathrm{L}^{-1}\right)$, the relative error on each single protein concentration 
Table III. Operating conditions for the series of experiments of the precipitation step of $\alpha$-lactalbumin.

\begin{tabular}{|c|c|c|c|c|c|c|}
\hline \multicolumn{7}{|c|}{ Series } \\
\hline Parameter & 1 & 2 & 3 & 4 & $5^{*}$ & 6 \\
\hline Feed & conc. PS 90 UF & PS $75 \mathrm{MF}$ & PS $75 \mathrm{MF}$ & PS $75 \mathrm{MF}$ & PS $75 \mathrm{MF}$ & conc. PS90 UF \\
\hline$C_{\alpha-L A}\left(g \cdot L^{-1}\right)$ & 6.4 & $2.3-19.2$ & 6.4 & 9.6 & 9.6 & 6.4 \\
\hline$P_{\alpha-L A} \quad(-)$ & 0.41 & 0.17 & 0.17 & 0.17 & 0.17 & 0.35-0.10** \\
\hline Precipitation $\mathrm{pH}$ & $3.0-4.2$ & $3.3-5.1$ & $3.3-4.2$ & 3.9 & 3.9 & 3.9 \\
\hline $\begin{array}{l}\text { Ionic strength } \\
\left(\mathrm{mol} \cdot \mathrm{L}^{-1}\right)\end{array}$ & 0.16 & 0 & 0.06 & 0 & 0 & $0.2(\mathrm{NaCl})$ \\
\hline Citrate $\left(\mathrm{mol} \cdot \mathrm{L}^{-1}\right)$ & 0 & 0 & 0 & $8.45 \times 10^{-3 * * *}$ & 0 & 0 \\
\hline Temperature $\left({ }^{\circ} \mathrm{C}\right)$ & 55 & 55 & 55 & 35 & 55 & 55 \\
\hline Washing steps & 2 & 2 & 2 & 2 & 1 & 1 \\
\hline $\begin{array}{l}\text { Solubilisation } \\
\text { solvent**** }\end{array}$ & $\begin{array}{c}\mathbf{H}_{\mathbf{2}} \mathbf{O} \\
0.05 \mathrm{~mol} \cdot \mathrm{L}^{-1} \mathbf{~ N a C l} \\
0.05 \mathrm{~mol} \cdot \mathrm{L}^{-1} \mathbf{C a C l}_{2}\end{array}$ & & & $\begin{array}{c}\mathbf{H}_{\mathbf{2}} \mathbf{O} \\
0.1 \mathrm{~mol} \cdot \mathrm{L}^{-1} \mathbf{C a C l}_{\mathbf{2}}\end{array}$ & & \\
\hline
\end{tabular}

Bold type: investigated parameter; * kinetics study: precipitation time 5-180 min; ** $\mathrm{P}_{\alpha-\mathrm{LA}}=0.37-0.10$ with addition of pure $\beta$-LG; $* * * \mathrm{NaH}_{2}$ citrate addition to optimum $\mathrm{pH}+0.3 \mathrm{pH}$ and then $\mathrm{H}_{3}$ citrate addition down to optimum $\mathrm{pH} ; * * * * \mathrm{pH}$ adjusted to 7.5 in every experiment.

was $\leq 0.1$ for BSA and IgGs in UF permeates; 0.005 for $\alpha$-LA and $\beta$-LG in initial feeds, UF retentates and supernatants (precipitation route), and 0.04 for $\alpha-\mathrm{LA}$ and $\beta$-LG in UF permeates.

\subsection{Calculations}

Protein transmission, $\operatorname{Tr}\left(\operatorname{Tr}=\frac{\mathrm{C}_{\mathrm{p}}}{\mathrm{C}_{\mathrm{r}}}\right.$ with $\mathrm{C}_{\mathrm{p}}, \mathrm{C}_{\mathrm{r}}$ protein concentration in the permeate, $\mathrm{p}$, and in the retentate, $\mathrm{r}$ ), was calculated with an error $\leq 0.05$.

Protein purity, $\mathrm{P}$, was calculated as $\mathrm{P}=$
$\frac{\mathrm{C}_{\mathrm{i}}}{\Sigma \mathrm{C}}$ with $\mathrm{C}_{\mathrm{i}}$ concentration of protein $\mathrm{i}$ in a given stream and $\Sigma \mathrm{C}$, overall protein concentration in the stream). The relative error on $\alpha$-LA purity in UF permeates was $\frac{\Delta \mathrm{P}}{\mathrm{P}} \leq$ 0.09 .

The relative error on purity of single proteins in the initial feed and of $\alpha$-LA in supernatants was: $\frac{\Delta \mathrm{P}}{\mathrm{P}} \leq 0.03$.

The yield of the precipitated $\alpha-\mathrm{LA}$ ratio, $\mathrm{R}_{\alpha-\mathrm{LA}}$ final $\alpha$-LA amount recovered/overall $\alpha$-LA amount implemented was calcu- lated as:

$$
\mathrm{R}_{\alpha-\mathrm{LA}}=1-\frac{\mathrm{C}_{\alpha-\mathrm{LA}, \mathrm{s}} \times \mathrm{V}_{\mathrm{s}}}{\mathrm{C}_{\alpha-\mathrm{LA}, \mathrm{i}} \times \mathrm{V}_{\mathrm{t}}}
$$

with $\mathrm{C}_{\alpha-\mathrm{LA}, \mathrm{s}}$ : concentration of $\alpha$-LA of the first supernatant of centrifugation;

$\mathrm{C}_{\alpha-\mathrm{LA}, \mathrm{i}}$ : initial concentration of $\alpha$-LA;

$\mathrm{V}_{\mathrm{s}}$ : volume of the first supernatant of centrifugation;

$\mathrm{V}_{\mathrm{i}}$ : total initial volume of implemented

protein solution.
$\quad$ The relative error on $\frac{\Delta \mathrm{V}_{\mathrm{s}}}{\mathrm{V}_{\mathrm{s}}}$ and $\frac{\Delta \mathrm{V}_{\mathrm{i}}}{\mathrm{V}_{\mathrm{i}}}$ was
$\leq 0.05$.

The relative error $\frac{\Delta R}{R}$ was $\leq 0.1$.

The yield $Y_{\alpha-L A}$ of $\alpha-L A$ after the UF run and after the final step of resolubilisation in the precipitation route were calculated according to the same mathematical equations applied to the final supernatant of centrifugation performed after the solubilisation step:

$$
Y_{\alpha-L A}=1-\frac{C_{\alpha-L A, f} \times V_{f}}{C_{\alpha-L A, i} \times V_{t}},
$$


with $C_{\alpha-L A, f}$ : concentration of $\alpha-L A$ of the final supernatant of centrifugation performed after the solubilisation step;

$\mathrm{C}_{\alpha-\mathrm{LA}, \mathrm{i}}$ : initial concentration of $\alpha-\mathrm{LA}$;

$\mathrm{V}_{\mathrm{f}}$ : volume of the final supernatant of centrifugation performed after the solubilisation step;

$\mathrm{V}_{\mathrm{i}}$ : total initial volume of implemented protein solution. 0.005 .

The relative error on $\frac{\Delta \mathrm{V}_{\mathrm{f}}}{\mathrm{V}_{\mathrm{f}}}$ and $\frac{\Delta \mathrm{V}_{\mathrm{i}}}{\mathrm{V}_{\mathrm{i}}}$ was $\leq$

The relative error on $Y_{\alpha-L A}$ was:

$$
\frac{\Delta \mathrm{Y}_{\alpha-\mathrm{LA}}}{\mathrm{Y}_{\alpha-\mathrm{LA}}} \leq 0.05 \text {. }
$$

A few experiments of ultrafiltration and precipitation were duplicated. The reproducibility for flux, J, protein concentration and volume of the streams was good and the standard deviation was low: $\mathrm{J} \pm 5 \mathrm{~L} \cdot \mathrm{h}^{-1} \cdot \mathrm{m}^{-2}$; $\operatorname{Tr}_{\alpha-L A} \pm 0.01 ; \operatorname{Tr}_{\beta L G} \pm 0.01 ; \mathrm{P} \pm 0.05 ;$ $\mathrm{Y} \pm 0.06$.

\section{RESULTS AND DISCUSSION}

\subsection{Ultrafiltration route}

\subsubsection{Comparison of two feeds (PS 90 microfiltrate; PS 90 ultrafiltrate)}

In both UF runs flux declined from 85 to around $40 \mathrm{~L} \cdot \mathrm{h}^{-1} \cdot \mathrm{m}^{-2}$ vs. VRR which increased with time up to around 8.0. Overall fouling and irreversible fouling were a little higher with the PS 90 microfiltrate. Figure 2 shows $\alpha$-LA and $\beta-\mathrm{LG}$ transmission versus VRR: $\operatorname{Tr}_{\alpha-L A}>\operatorname{Tr}_{\beta-L G}$ but $\operatorname{Tr}_{\alpha \text {-LA }}$ was smaller than the theoretical transmission calculated according to Ferry's equation when $\beta$-LG transmission was used for the determination of the fouled pore radius. Protein transmission with PS 90 microfiltrate was three to four times lower than with PS 90 ultrafiltrate. As transmissions of BSA and IgG contained in the PS 90 microfiltrate only were zero, $\alpha$-LA purity in the UF permeate was improved.

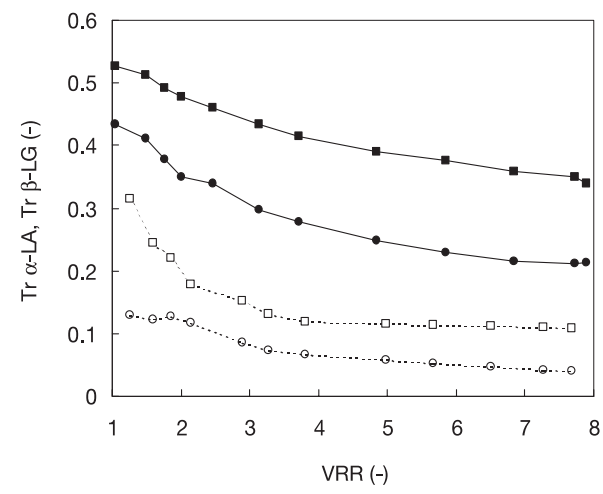

Figure 2. Transmission of $\alpha$-lactalbumin $\left(\operatorname{Tr}_{\alpha-L A}\right.$, $\square, \boldsymbol{\square})$ and of $\beta$-lactoglobulin $\left(\operatorname{Tr}_{\beta-L G}, O, 0\right)$ versus volume reduction ratio, VRR for the PS 90 microfiltrate (open signs) and for the PS 90 ultrafiltrate (closed signs) at protein concentration, $\mathrm{C}=1.6 \mathrm{~g} \cdot \mathrm{L}^{-1} ; \mathrm{pH} 7.0 ; 0.2 \mathrm{~mol} \mathrm{NaCl} \cdot \mathrm{L}^{-1}$. Operating conditions: see text.

$\alpha$-LA purity was stable with VRR and similar for PS 90 ultrafiltrate and PS 90 microfiltrate : 0.51 (vs. 0.43 initially) and 0.56 (vs. 0.33 initially), respectively, but $\alpha$-LA yield (a function of both initial concentration and transmission) was 0.57 for PS 90 ultrafiltrate vs. 0.32 for PS 90 microfiltrate.

\subsubsection{Ionic strength, I, and protein concentration, C (feed: PS 90 ultrafiltrate)}

Flux decline vs. VRR was similar, fast then slower, whatever C and I (Fig. 3a). The flux values were a little lower with both low I and high protein concentration; at low I $\left(0.04 \mathrm{~mol} \cdot \mathrm{L}^{-1}\right)$, the higher the protein concentration, the smaller J. Transmission of $\alpha$-LA depended on I only when VRR was $<4$, but was fairly independent of $I$ at a higher VRR $\left(\operatorname{Tr}_{\alpha-L A}: 0.11\right.$ to 0.13$)$ (Fig. 3b). $\beta$-LG transmission remained inferior to $\alpha$-LA transmission (Fig. 3c) and ranged from $0.15-0.04$ (VRR 1-2) to $0.05-$ 0.02 (end of the UF run). 

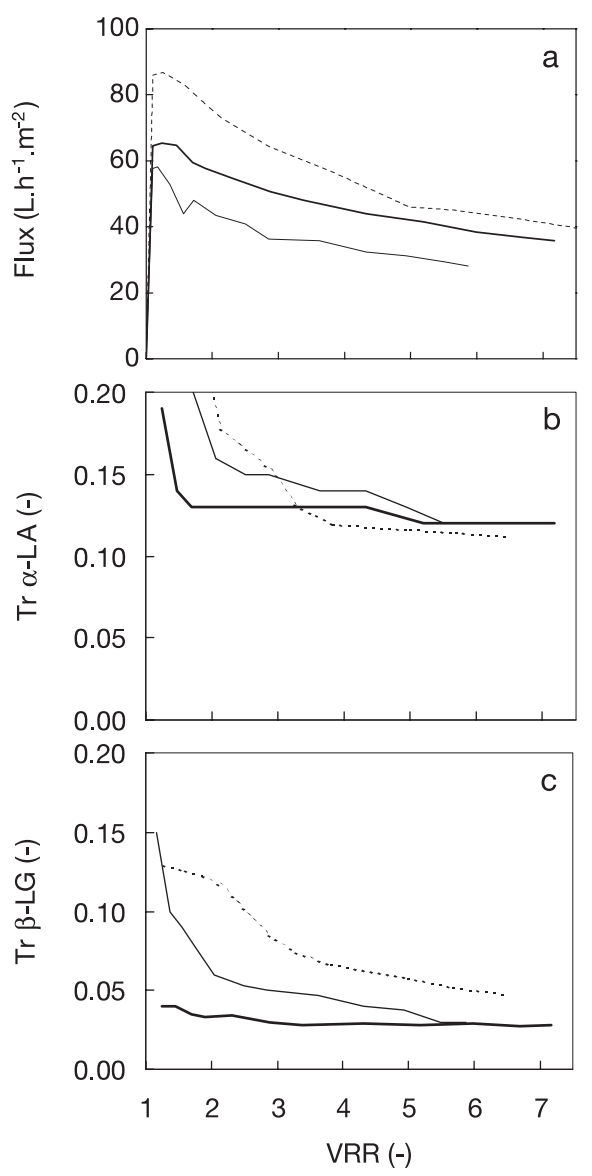

Figure 3. Flux (a), transmission of $\alpha-$ lactalbumin $\left(\operatorname{Tr}_{\alpha-L A}, b\right)$ and of $\beta$-lactoglobulin $\left(\operatorname{Tr}_{\beta-L G}, c\right)$ versus volume reduction ratio, VRR for total initial concentrations of PS 90 ultrafiltrate and ionic strength $(\mathrm{NaCl})$. (------) $1.6 \mathrm{~g} \cdot \mathrm{L}^{-1}, 0.20 \mathrm{~mol} \cdot \mathrm{L}^{-1}$; ( $0.04 \mathrm{~mol} \cdot \mathrm{L}^{-1} ;(-) 7.0 \mathrm{~g} \cdot \mathrm{L}^{-1}, 0.04 \mathrm{~mol} \cdot \mathrm{L}^{-1}$. Operating conditions: Céram $50 \mathrm{~kg} \cdot \mathrm{mol}^{-1}$ membrane, see text for details.

Thus, both low ionic strength and low $\beta$-LG concentration helped to minimise $\beta$-LG transmission, close to 0.03 . From the PS 90 ultrafiltrate, the purity was 0.66 and the yield was 0.28 for $\alpha$-LA in the permeate (Fig. 4).

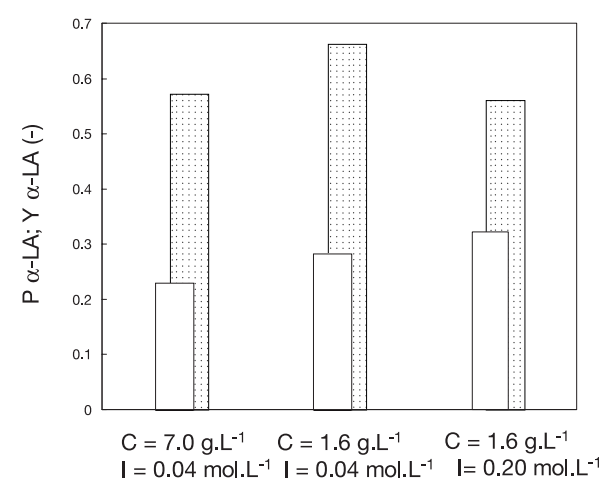

Figure 4. $\alpha$-lactalbumin purity, $\mathrm{P}_{\alpha-\mathrm{LA}}$ (dotted bars) and recovery yield, $Y_{\alpha-L A}$ (open bars) in the permeate after $3.5 \mathrm{~h}$ ultrafiltration for different total initial protein concentrations, $\mathrm{C}$ and ionic strength $(\mathrm{NaCl})$, I of PS90 ultrafiltrate with Céram $50 \mathrm{~kg} \cdot \mathrm{mol}^{-1}$ membrane; Transmembrane pressure: 1.0 bar. Operating conditions: see text and Figure 3 for details.

\subsubsection{Transmembrane pressure, TMP 0.5-2.0 bar (feed: PS 90 microfiltrate, $7.0 \mathrm{~g} \cdot \mathrm{L}^{-1}$ protein concentration, $I=0.04 \mathrm{~mol} \cdot \mathrm{L}^{-1}$ )}

The higher the TMP, the higher the flux, with a trend which suggests that a limiting flux could be attained at higher pressure (Fig. 5a). Figure 5b shows a noteworthy decrease in protein transmission with increasing TMP over 1 bar; thus, TMP in the range $0.5-1.0$ bar is better in accordance with the results reported with PS 90 ultrafiltrate (3.1.1.; 3.1.2.).

\subsubsection{Evaluation of the ultrafiltration route}

From a starting feed with satisfactory initial $\alpha$-lactalbumin purity ( 0.43 with PS 90 ultrafiltrate, Tab. I) the $50 \mathrm{~kg} \cdot \mathrm{mol}^{-1} \mathrm{UF}$ step produced a permeate enriched in $\alpha$-LA with purity around 0.66 and poor yield of 0.28 , although operated with favourable conditions of low ionic strength and low protein concentration. These disappointing 


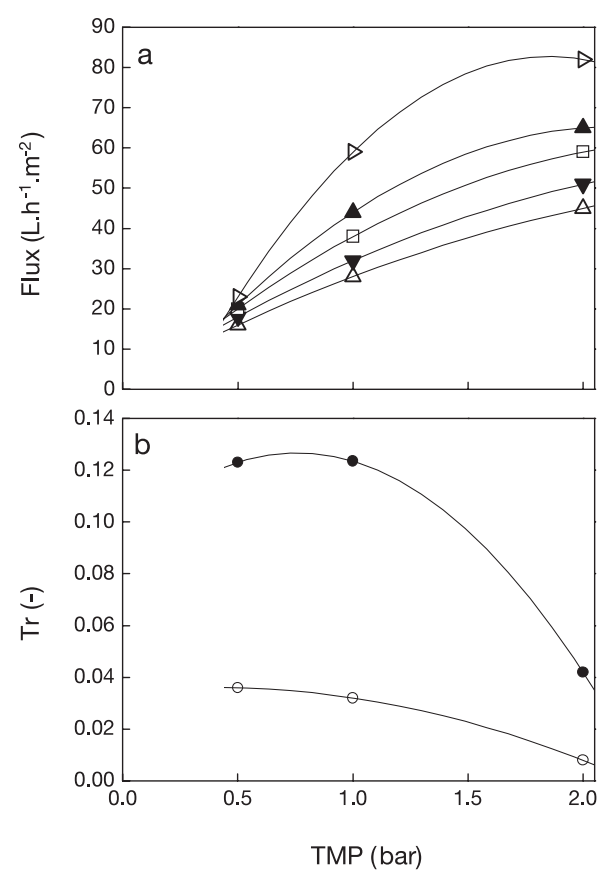

Figure 5. Flux maximum $(\mathrm{l}>)$ and after $0.5 \mathrm{~h}$ $(\mathrm{s}), 1 \mathrm{~h}(\square), 2 \mathrm{~h}(\mathrm{t})$ and $3 \mathrm{~h}(\Delta)$ ultrafiltration (a); and transmission $\mathrm{Tr}$, of $\alpha$-lactalbumin (1) and of $\beta$-lactoglobulin (O) (b) of PS 90 microfiltrate (7.0 g. $\mathrm{L}^{-1}$; ionic strength, $\mathrm{I}=0.04 \mathrm{~mol} \mathrm{NaCl} \cdot \mathrm{L}^{-1}$ ) versus transmembrane pressure, TMP. Operating conditions: Céram $50 \mathrm{~kg} \cdot \mathrm{mol}^{-1}$ membrane, see text for details.

results could have been anticipated, since $\alpha$-LA purity can only be increased by decreasing $\beta$-LG transmission down to 0 , which simultaneously decreases $\alpha$-LA transmission and consequently yield. Whey protein transmission in UF is governed by the combined effect of the average fouled pore size and electrostatic interactions of the fouled membrane, of which the charge is given by adsorbed $\beta-\mathrm{LG}$ and proteins in the fluid, which depend on protein concentration at the membrane wall and thereon retentate protein concentration and filtration flux. Our results, obtained through variations of proper operating conditions, illustrate those principles well [11].

Thus, the only way to significantly enhance $\alpha$-LA purity and yield is to operate successive UF steps, at least 3, for purity and to operate diafiltration steps for yield. It is likely that such a complicated process would be economically unacceptable.

\subsection{Precipitation route}

\subsubsection{Influence of processing conditions}

The systematic investigations were mostly performed with the PS 75 microfiltrate (Tab. III). The main conclusions were as follows:

- on the whole, $\alpha$-LA purity in the range $0.77-0.83$ and final yield in the range 0.71-0.46 were quite promising (Tab. IV);

- in the range of concentration of $\alpha$-LA between 6.4 and $9.6 \mathrm{~g} \cdot \mathrm{L}^{-1}$ and at $\mathrm{pH}$ of 3.9 a good precipitation yield $(\mathrm{R}>0.88)$ (smaller at high $\mathrm{pH}$ and low concentration) was achieved;

- low I is to be preferred, since the precipitation yield was not improved when I varied from 0 to $0.16 \mathrm{~mol} \cdot \mathrm{L}^{-1}$; accordingly, WPC feed with zero ionic strength is the best feed;

- heat treatment was better at $55{ }^{\circ} \mathrm{C}$ than at $35{ }^{\circ} \mathrm{C}$ : the overall recovery yield, $\mathrm{Y}_{\alpha-\mathrm{LA}}$, was 0.71 vs. 0.46 in spite of addition of citrate ions for calcium complexation at $35{ }^{\circ} \mathrm{C}$ (Tab. IV); further, such an addition might improve the yield at $55^{\circ} \mathrm{C}$. Besides, no significant difference for $\alpha$-LA purity $(0.77 / 0.83)$ was observed (Tab. IV) despite a lower co-precipitation of BSA and Ig at a lower temperature;

- heat treatment time for $5-10 \mathrm{~min}$ at $55^{\circ} \mathrm{C}$ allowed the achievement of good yields of precipitation $\left(\mathrm{R}_{\alpha-\mathrm{LA}}: 0.82-0.92\right)$. The stationary precipitation yield observed as early as $30 \mathrm{~min}$ was 1.19 time higher, $\mathrm{R}_{\alpha-\mathrm{LA}}=0.95-0.98$. An assessment of the energy cost should be done to evaluate what heat treatment time should be selected;

- a single washing step was enough, since the second washing step caused losses of precipitate, detrimental to $\alpha$-LA yield, with no significant increase in $\alpha$-LA purity (Tab. IV); 
Table IV. Performances of the precipitation route with acid casein whey (concentrated PS 90 ultrafiltrate and PS 75 microfiltrate) and with rennet casein whey [5]: more performing conditions.

\begin{tabular}{|c|c|c|c|c|c|c|c|c|}
\hline & \multicolumn{4}{|c|}{$\begin{array}{c}\text { Concentrated } \\
\text { PS } 90 \text { ultrafiltrate }\end{array}$} & \multicolumn{2}{|c|}{ PS 75 microfiltrate } & \multicolumn{2}{|c|}{ Rennet casein whey } \\
\hline Initial $P_{\alpha-L A}+\beta-L G(-)$ & \multicolumn{4}{|c|}{1.00} & \multicolumn{2}{|c|}{0.98} & \multicolumn{2}{|c|}{0.88} \\
\hline Initial $P_{\alpha-L A}(-)$ & \multicolumn{4}{|c|}{0.35} & \multicolumn{2}{|c|}{0.17} & \multicolumn{2}{|c|}{0.26} \\
\hline $\mathrm{C}_{\mathrm{Ca}} / \mathrm{C}_{\alpha-\mathrm{LA}}$ (molar ratio) (-) & \multicolumn{4}{|c|}{7} & \multicolumn{2}{|c|}{11} & \multicolumn{2}{|c|}{38} \\
\hline Initial $C_{\alpha-L A}\left(g \cdot L^{-1}\right)$ & \multicolumn{4}{|c|}{4.3} & 9 & 6 & \multicolumn{2}{|c|}{1.8} \\
\hline $\mathrm{T}\left({ }^{\circ} \mathrm{C}\right) ; \mathrm{t}(\mathrm{min})$. & \multicolumn{4}{|c|}{$55 ; 120$} & $55 ; 120$ & $35 ; 120$ & \multicolumn{2}{|c|}{$55 ; 30$} \\
\hline Pure water washing steps & 2 & 1 & 2 & 1 & 2 & 2 & 2 & 2 \\
\hline $\begin{array}{l}\text { Solubilisation solvent } \\
(\mathrm{pH} 7.5)\end{array}$ & $\mathrm{H}_{2} \mathrm{O}$ & $\mathrm{H}_{2} \mathrm{O}$ & \multicolumn{2}{|c|}{$\begin{array}{c}\mathrm{CaCl}_{2} \\
0.05 \mathrm{~mol} \cdot \mathrm{L}^{-1}\end{array}$} & $\mathrm{H}_{2} \mathrm{O}$ & $\mathrm{H}_{2} \mathrm{O}$ & $\begin{array}{c}\mathrm{CaCl}^{\bullet} \\
0.1 \mathrm{~mol} \cdot \mathrm{L}^{-1}\end{array}$ & $\begin{array}{c}\mathrm{CaCl}_{2}^{\bullet} \\
0.1 \mathrm{~mol} \cdot \mathrm{L}^{-1}\end{array}$ \\
\hline $\mathrm{R}_{\alpha-\mathrm{LA}}$, precipitation (-) & \multicolumn{4}{|c|}{0.87} & 0.96 & 0.88 & \multicolumn{2}{|c|}{0.81} \\
\hline $\begin{array}{l}\mathrm{P}_{\alpha-\mathrm{LA}}, \text { final } \\
\text { supernatant }{ }_{(-)}\end{array}$ & 0.96 & $0.94^{\bullet}$ & $>0.99$ & $0.99^{\bullet}$ & 0.77 & 0.83 & 0.56 & 0.79 \\
\hline $\begin{array}{l}\mathrm{Y}_{\alpha-\mathrm{LA}}, \text { final } \\
\text { supernatant }{ }^{\circ}{ }_{(-)}\end{array}$ & 0.66 & $0.83^{\bullet}$ & 0.55 & $0.70^{\bullet}$ & 0.71 & 0.46 & 0.81 & 0.65 \\
\hline $\begin{array}{l}\text { Insoluble (final } \\
\text { resolubilisation step) }\end{array}$ & No & No & Yes & Yes & Yes & Yes & No & No \\
\hline
\end{tabular}

\footnotetext{
P: purity; R, Y: yield; ${ }^{\bullet}=$ calculated from mass balance; ${ }^{\cdot \bullet}=$ reproducibility of purity: \pm 0.05 ; $=$ reproducibility of yield: \pm 0.06 .
}

- water (pH 7.5) was the simplest resolubilisation solvent since neither $\mathrm{NaCl}$ nor $\mathrm{CaCl}_{2}$ improved $\alpha$-LA purity, in contrast with what could be expected from rennet whey ([5]; Tab. IV). It is noteworthy that either apo- $\alpha$-LA or $\alpha-\mathrm{LA}-\mathrm{Ca}^{2+}$ can be recovered depending on the nature of ions, $\mathrm{Na}^{+}$or $\mathrm{Ca}^{2+}$, respectively, present in the resolubilisation solvent [5]. Further, by using $\mathrm{Ca}^{2+}$ as solubilisation solvent, $\mathrm{IgG}$ (when present in protein fraction) coprecipitated with $\alpha$-LA remains insoluble, yielding improved final $\alpha$-LA purity starting from rennet casein whey [5]. With our own starting material impoverished in Ig (and BSA), such a phenomenon was not observed. Furthermore, a remaining insoluble fraction was systematically observed with the PS 75 microfiltrate as a feed. It is likely that the insoluble matter is composed of BSA and IgG, which contaminated PS 75 microfiltrate contrarily to concentrated PS 90 ultrafiltrate. Indeed, BSA and $\operatorname{IgG}$ coprecipitate with $\alpha$-LA in the precipitation step, but do not resolubilise during the resolubilisation step $[3,5]$.
The most striking performance of the precipitation route was achieved with the concentrated PS 90 ultrafiltrate, at a precipitation $\mathrm{pH}$ of 3.9 with one washing step and water ( $\mathrm{pH} 7.5)$ as a solubilisation solvent (Tab. IV): $\alpha$-LA purity $>0.94$; yield in the range 0.55-0.83; no insoluble fraction remaining after the solubilisation step with pure water.

Besides, whatever the feed and process conditions, the supernatant produced by the 1st precipitation step was a quite pure $\beta$-LG fraction $\left(\mathrm{P}_{\beta-\mathrm{LG}}>0.90\right)$ with a yield over 0.90 [13].

\subsubsection{Evaluation of the precipitation route}

The objective was to produce resolubilised $\alpha$-LA with high purity and satisfactory yield.

The existing knowledge about $\alpha$-LA separation through its precipitation from rennet whey protein concentrate [5] and acid casein whey protein concentrate [9] was successfully adapted to UF and MF permeates from acid casein whey. 
With such feeds the optimum concentration of $\alpha$-LA for precipitation is $2-5$ times higher than that for de-calcified $\alpha$-LA (rennet whey acidified to 3.9-4.0) as reported by Bramaud et al. [5], which indicates a worse efficiency, probably due to the thermal, physicochemical and mechanical history of the feeds used: concentrated PS 90 ultrafiltrate and PS 75 microfiltrate. The significant difference in the two fluids can be explained by the higher initial $\alpha$-LA purity in the ultrafiltrate. It is interesting that these two fluids yielded better performance of purity and yield as compared with what is reported when using rennet whey $[3,5]$, even though with the latter feed similar yield was achieved by processing smaller initial $\alpha$-LA concentration and lower $\mathrm{pH}$. The major reasons for these good performances regarding the purity of $\alpha$-LA are the higher initial $\alpha$-LA purity (0.35 for concentrated PS 90 ultrafiltrate vs. 0.26 for rennet whey) and the absence of contaminating BSA and IgG in the PS 90 ultrafiltrate, and their very low concentration in the PS 75 microfiltrate. But, even if very low, that residual BSA and $\mathrm{IgG}$ concentration in a whey protein fraction should be avoided since it generated an insoluble fraction after the resolubilisation step, as for PS 75 microfiltrate. It generated insoluble fraction after the resolubilisation step. The purity of the $\beta$ LG co-fraction was also over 0.90 (no glycomacropeptide) with a very high overall yield, close to or over 0.90 [13].

Now, the major principles of the twostep process reported in this paper for preparing highly purified $\alpha$-LA (purity $>0.9$ ) with fairly good yield (up to 0.83 ) and with a high purity $(>0.9) \beta$-LG co-fraction are known. However, purity is far from being the only and major criterion, since functional and/or biological properties are required for this kind of purified protein fraction. A few major scientific and technological points will have to be tackled in future studies. The first ones are: what is the structure and what is the function of $\alpha$ LA in the successive streams obtained through such a process, including the starting fluid (rennet whey, sweet cheese whey, acid cheese whey, acid casein whey, ...)? The second one is: how to modify the process steps and/or the operating conditions so that the targeted structure and properties are preserved or altered as little as possible?

\section{CONCLUSION}

The novel cascade investigated was shown to be feasible and competitive to the process described by Bramaud et al. [5]. The first step of fundamental role aimed at producing a tailor-made feed with both enhanced $\alpha$-LA purity and decreased content of BSA and Ig. The second step performed according to the ultrafiltration route was strongly limited by insufficient yield due to a low transmission of $\alpha$-LA during UF, since the aim is to lower $\beta$-LG to 0 , so as to get high purity of $\alpha$-LA in the permeate. As opposed to this deceiving step, the precipitation route appeared to be satisfactory for producing fully soluble $\alpha-$ LA with a purity over 0.94 and an acceptable yield between 0.46 and 0.83 .

The next step of the work should be devoted to the optimisation of the whole cascade with the aim of producing pure $\alpha$ LA in such a structure (N-like, A-like conformer, and intermediate states) that it keeps its targeted functional or biological properties throughout a process with a reduced number of steps and improved overall yield.

Acknowledgments: This work was supported within the framework of a European Commission subsidised project (AIR 2 - CT 93-1207). We would like to thank J. Fauquant and N. Hamard for helpful technical assistance with the clarification step of some WPCs at the Technology Hall of LRTL, and D. Lucas for performing the final concentration of PS 90 ultrafiltrate.

\section{LIST OF ABBREVIATIONS:}

$\alpha$-LA: $\alpha$-lactalbumin; $\beta$-LG: $\beta$-lactoglobulin; BSA: bovine serum albumin; DF: diafiltration; GMP: glycomacropeptide; 
Ig: immunoglobulins; IgG: immunoglobulin G; DF: diafiltration; MF: microfiltration; UF: ultrafiltration; WPC: whey protein concentrate; $\mathbf{C}$ : concentration; $\mathbf{C}_{\text {tot }}$ : total concentration; I: ionic strength $\left(\mathrm{mol}^{-1}\right)$; $\mathbf{J}$ : permeate flux $\left(\mathrm{L} \cdot \mathrm{h}^{-1} \cdot \mathrm{m}^{-2}\right)$; MM: molecular mass $\left(\mathrm{kg} \cdot \mathrm{mol}^{-1}\right)$; MMCO: molecular mass cut-off $\left(\mathrm{kg} \cdot \mathrm{mol}^{-1}\right)$; OD: optical density (absorbance units); P: protein purity (-); $\mathbf{R}$ : precipitation yield (-); T: temperature $\left({ }^{\circ} \mathrm{C}\right)$; Tr: transmission (-); V: volume (L); VRR: volume reduction ratio (-); $\Delta \mathbf{P}$ : transmembrane pressure (bar).

\section{REFERENCES}

[1] Blazey N.D., Knights R.J., Wu C., Membrane filtered milk proteins varying in composition and functional properties, Int. Patent Appl. PCT WO 00/51440, 2000.

[2] Bottomley R.C., Process for obtaining concentrates having a high $\alpha$-lactalbumin content from whey, Eur. Patent Appl. EP 0311283 A2, 1989.

[3] Bramaud C., Optimisation of a fractionation process of whey proteins including selective precipitation and membrane separation, Ph.D. thesis, Univ. P. Sabatier, Toulouse, France, 1995.

[4] Bramaud C., Aimar P., Daufin G., Thermal isoelectric precipitation of $\alpha$-lactalbumin from a whey protein concentrate: influence of protein calcium complexation. Biotechnol. Bioeng. 47 (1995) 121-130.

[5] Bramaud C., Aimar P., Daufin G., Optimisation of a whey protein fractionation process based on the selective precipitation of $\alpha$-lactalbumin, Lait 77 (1997) 411-423.

[6] Daufin G., Radenac J.F., Gésan G., Kerhervé F.L., Le Berre O., Michel F., Merin U., A novel rig design for ultra and microfiltration for experiments, Separ. Sci. Technol. 28 (1993) 2635-2642.

[7] de Wit J.N., Bronts H., Process for the recovery of $\alpha$-lactalbumin and $\beta$-lactoglobulin from a whey protein product, Eur. Patent Appl. EP 0604684 A1, 1994.

[8] Ferry J.D., Ultrafilter membranes and ultrafiltration, Chem. Rev. 18 (1936) 373-455.

[9] Gésan-Guiziou G., Daufin G., Timmer M., Allersma D., van der Horst C., Process steps for the preparation of purified fractions of alpha-lactalbumin and beta-lactoglobulin from whey protein concentrates, J. Dairy Res. 66 (1999) 225-236.

[10] Jensen J., Larsen P.H., Method for obtaining high-quality protein products from whey, Int. Patent Appl. PCT WO 93/21781, 1993.
[11] Lucas D., Rabiller-Baudry M., Millesime L., Chaufer B., Daufin G., Extraction of $\alpha$-lactalbumin from whey protein concentrate with modified inorganic membranes, J. Membrane Sci. 148 (1998) 1-12.

[12] Matsuno I., Uchida Y., Shimatani M., Koutake M., Nishizaki S., Procédé de fabrication d'une fraction de lait à teneur élevée en alpha-lactalbumine et produit obtenu par la mise en oeuvre de ce procédé, Fr. 2669810 A1, 1992.

[13] Muller A., Process for obtaining high purity $\alpha$-lactalbumin: elementary steps of whey proteins fractionation and cascade set-up, Ph.D. thesis, ENSA Rennes, France, 1996.

[14] Muller A., Daufin G., Chaufer B., Ultrafiltration modes of operation for the separation of $\alpha$-lactalbumin from acid casein whey, $\mathrm{J}$. Membrane Sci. 153 (1999) 9-21.

[15] Muller A., Chaufer B., Merin U., Daufin G., Prepurification of $\alpha$ tactalbumin with ultrafiltration ceramic membranes from acid casein whey: study of operating conditions, Lait 83 (2003) 111-129.

[16] Outinen M., Harju M., Tassavainen O., Antila P., Process for fractionating whey proteins and the components obtained, Int. Patent Appl. PCT WO 95/19714, 1995.

[17] Pearce R.J., Thermal separation of $\beta$-lactoglobulin and $\alpha$-lactalbumin in bovine Cheddar cheese whey, Aust. J. Dairy Technol. 38 (1983) 144-148.

[18] Pearce R.J., Whey protein fractions, Int Patent Appl. PCT WO 88/06673, 1988.

[19] Pierre A., Fauquant J., Principles for an industrial process for the fractionation of whey protein, Lait 66 (1986) 405-419.

[20] Roger L., Maubois J.-L., Brulé G., Piot M., Product enriched in $\alpha$-lactalbumin. Obtention from whey and applications of the product, Fr. Patent Appl. FR 7916 482, 1979.

[21] Shimatani M., Uchida Y., Matsuno I., Sugawara M., Nakano T., Process for the manufacture of a composition with a high $\alpha$ lactalbumin content, Fr. Patent Appl. FR 2 $671697,1992$.

[22] Shimatani M., Uchida Y., Matsuno I., Oyoshi M., Ishiyama Y., Process for the manufacture of a composition containing sialic acids, Fr. Patent Appl. FR 2671696, 1992.

[23] Stack F.M., Hennessy M., Mulvihill D., O'Kennedy B.T., Process for the fractionation of whey constituents, Int. Patent Appl. PCT WO 95/34216, 1995.

[24] Wu C., Whey treatment process for achieving high concentration of $(\alpha)$-lactalbumin, Int. Patent Appl. PCT WO 01/05243 A1, 2001. 